\title{
NOVEL AND RAPID TECHNOLOGY FOR DISSECTING AND REMOVINGMICROBIAL COMMUNITY IN AQUATIC ENVIRONMENT
}

\section{Mohamed I. Azzam* and Sabah S. Ibrahim}

Central Laboratory for Environmental Quality Monitoring, National Water Research Center, Egypt

*E-mail: dr-mohamed-azzam@ hotmail.com

Corresponding Author: Mohamed I, Azzam, Central Lab for Environmental Quality Monitoring, National Water Research Center, P.O. Box 13621/6, El- Kanater, Egypt. E-mail: dr-mohamedazzam@hotmail.com

Key Words: Eco-diversity, Elimination, Management, Metagenomics, Nanoparticles, Water quality.

\begin{abstract}
:
The present study aims to integrate the benefits of Illumina microbial sequencing approaches using novel prepared copper oxide $(\mathrm{CuO})$ nanoparticles for improving water quality monitoring and management. Our results showed rapid and accurate discovery of novel different microbial compositions in the collected water samples. The domestic drains were had pathogenic microbes as viruses, Alpha-, BetaGamma proteobacteria, Bacteroidia, Deinococci, Bacilli also Clostridia with variety quantitive. The class Pseudomonadales were found to be higher in quantity in all drains outfall. Viruses, including Enteroviruses and hepatitis $\mathrm{A}$ and $\mathrm{E}$ species were found out in high volume of domestic drains in comparison with the agricultural and industrial drains. On the other hand, our results showed that decreasing and removing microbial pathogens using prepared copper oxide nanoparticles (CuO NPs) by quick precipitation method. The highest antibacterial activity was notified for CuO NPs with the optimum concentration $10^{2} \mu \mathrm{g} / \mathrm{mL}$ were ranged between 92 to $96 \%$ after contact time $24 \mathrm{~h}$ at $35^{\circ} \mathrm{C}$. The shaking during the treatment gave a positive effect removing with $\mathrm{CuO}$ NPs. Concluding remarks highlighted the potential of nanoparticles and Illumina mix as accurate, simple method. The study recommended future efforts to apply this as a robust, rapid and powerful metagenomics technology to detecting other disease-causing agents of public health concern to update and control water pollution.
\end{abstract}

\section{INTRODUCTION}

Increasing demands on clean water for many purposes as drinking, industrial andirrigation purposes, Clean water sources is shorted to meet increasing of population, increasingindustrial demands and other reasons. wastewater usage is one of the most source available to meet the clean 
water demands. pathogens and hazard chemicals which come from wastewater had an effects on health (Silva et al., 2009).

Copper (II) oxide is semiconducting material have amonoclinic structure systems, which having useful physical and chemical properties as superconductivity at relatively stable, high temperature, photovoltaic properties, and has antimicrobial effect (Rene et al., 2009). $\mathrm{CuO}$ nanoparticles have different technology applications as catalysis (Zhou et al., 2006), batteries due to high electrochemical capacity (Anandan et al., 2012), and gas sensors (Borgohain and Mahamuni, 2002). $\mathrm{CuO}$ nanoparticles synthesized by different methods as sonochemical technique (Anandan et al., 2012), electrochemical method (Borgohain and Mahamuni, 2002), high temperature combustion (Chang and Zeng, 2004) andnovel quick precipitation method (Zhu et al., 2004).

Removing organic pollutants from sewage water such as nitrogen, sulfur and carbon was considered a hot issue using specific microorganisms. bacterial community exists inactivated microbial state. Many methodologies were used for remediation wastewater of plants such as culture-dependent and culture-independent. Using various technologies for sequenced and analyzed structure and framework of microorganisms as 16S rRNA gene, 454 pyrosequencing, metagenomic sequencing where this tools used for microbial estimation from different domestic agricultural drains (Ye et al., 2012; Sanchez et al., 2013; Ye and Zhang, 2013).

Approach clone library sequencing can give non-accurate results deep-rooted alignment of planning (Aird et al., 2011; Ye et al., 2012). Some technologies evaluated Illumina sequencing technology where are an inventive practice to microbial genome (Albertsen et al., 2006; Bragg and Tyson, 2014). Several studies were evaluated anaerobic microbial structure using method 454 pyrosequencing (Wong et al., 2013; Li et al., 2013; Sundberg et al., 2013).

Illumina sequencing technology is a low-cost andeffective method when compared with 454 pyrosequencing investigate microbial community structure (Mardis, 2008 and Glenn, 2011) where it has been used for investigation microbial community from water samples (Mackelprang et al., 2011), also samples from the ocean (Mason et al., 2014). Anaerobic digested sludge (Ju et al. 2014). A study has tried to analyze complete data of microbiome from digested sludge samples (Yang et al., 2014). fecal indicators pollutants such as Escherichia coli or enterococci is being founded in the effluent part of wastewater samples, there are other disease-causing agents, shuch as bacteria and viruses which may be presented in fecal indicators which transmitted throw different carriers in environment. Ejection of the disease-causing agents is important for reutilization of water with measurement of 
pathogenic microorganisms in the environment (Varela and Manaia, 2013). Pathogenic bacteria "Mycobacteria" has never been observed and monitored to be measure for human and animal infection in wastewater where some researchers have quantified the presence of Mycobacteria in the drainage and surface water samples and they reported that Pathogenic bacteria "Mycobacteria" were not expected to be detected by known parameters. (Radomski et al., 2011). Viruses were reported to be non-predictable in the polluted water by given parameters (Savichtcheva and Okabe,2006).

Viruses are dangerous for animals and human health more bacteria, where they diffused easily (Rosa et al.,2010).

This study is important to analyses and dissect the microbiome structure from various parts.Using samples from El-Rahawy, Tala, Sabal drains in Egypt. Detecting concentration of viruses and mycobacteria. Using metagenomic sequencing technology. Pathogenic microbial species present of drainage water.

\section{MATERIALS AND METHODS COLLECTION OF SAMPLES}

According to Standard Methods for Examination of Water and Wastewater water samples the water samples analysis was carried out (APHA, 2012). Samples of water were collected in clean and sterile polyethylene plastic bottles. Various drains outfalls along the River Nile at Rosetta branch were chosen for sample collection and represent the major sector in Egypt, including El-Rahawy drain (R), Sabal drain (S), El-Tahreer drain (E), Zawiet El-Bahr drain (Z) and Tala drain (T) for 24 $\mathrm{h}$ after every $30 \mathrm{~min}$. Drains mixed from sewage, agricultural and industrial wastes.

Samples were collected under consistent sampling procedures such that: presence of ample air space in the bottles (at least $2.5 \mathrm{~cm}$ ) to facilitate mixing by shaking, keeping sampling bottles closed until it is to be filled, avoiding external contamination during sample collection, avoiding internal contamination of stopper or cap and bottle neck and filling container without rinsing. Allsamples collected for either chemical or bacteriological detection and immediately forwarded to the Central Laboratory for Environmental Quality Monitoring (CLEQM) National Water Research Center (NWRC), Cairo, Egypt in an iced cooler.

Preparation of Copper oxide nanoparticles (CuO NPs)

Copper oxide nanoparticles with tetraoctylammonium bromide (TOAB) surfactant were prepared using precipitation method. $\mathrm{CuO}$ NPs stabilized with TOAB surfactant. Dissolving about $15.00 \mathrm{~g}$ of $\mathrm{CuSO}_{4} .5 \mathrm{H}_{2} \mathrm{O}$ using $2.34 \mathrm{~g}$ of tetraoctylammonium bromide surfactant in $150 \mathrm{~mL}$ of ionized water for prepare (CuO-TOAB). Different size of $\mathrm{CuO}$ 
NPs was prepared at 65,75 and $85^{\circ} \mathrm{C}$ using tereflux capacitor. Heating and stirring for about $15 \mathrm{~min}$ at $150 \mathrm{rpm}$. About $2.0 \mathrm{M}$ of sodium hydroxide were added to $100 \mathrm{ml}$ of the prepared solution. Black precipitate (ppt) was collected and washing by the ionized water then allowed to dry.

\section{Physico-chemical analysis}

All field parameters were measured in the field and rechecked in laboratory to ensure data accuracy; Temperature, $\mathrm{pH}$, dissolved oxygen (DO), electric conductivity (EC) and total dissolved solids (TDS) were measured in water samples by using the multi-probe system, model Hydralab-Surveyor, Germany. Once the samples were received in the lab, they were manually mixed by shaking and examined as follows: Ammonia $\left(\mathrm{NH}_{3}\right)$ measured by using Kedah method . Nephelometric turbidity meter $\mathrm{HACH}$ using measured turbidity . (BOD) is known by Biochemical oxygen demand measuredd by ORION BOD model 890 . (COD) is known Chemical Oxygen Demand tested using potassium permanganate method. Total hardness, Calcium hardness (Ca. hardness), and Magnesium hardness (Mg. hardness) measured by Titrimetric Method. Chloride $\left(\mathrm{Cl}^{-}\right)$measured by Argentometric method. Nitrate $\left(\mathrm{NO}_{3}{ }^{-}\right)$, Nitrite

$\left(\mathrm{NO}_{2}^{-}\right)$, Phosphate $\left(\mathrm{PO}_{4}{ }^{3-}\right)$, and Sulphate $\left(\mathrm{SO}_{4}{ }^{2-}\right)$ were measured by Ion Chromatography. The concentrations of major cations, Calcium $\left(\mathrm{Ca}^{2+}\right)$, Sodium $\left(\mathrm{Na}^{+}\right)$, Magnesium $\left(\mathrm{Mg}^{2+}\right)$ and Potassium

$\left(\mathrm{K}^{+}\right)$. heavy metals as arsenic $\left(\mathrm{As}^{+2}\right)$, cadmium $\left(\mathrm{Cd}^{+2}\right)$, chromium $\left(\mathrm{Cr}^{+3}\right)$, copper $\left(\mathrm{Cu}^{+2}\right)$, zink $\left(\mathrm{Zn}^{+2}\right)$, lead $\left(\mathrm{Pb}^{+2}\right)$, nickel $\left(\mathrm{Ni}^{+2}\right)$, aluminum $\left(\mathrm{Al}^{+3}\right)$, manganese $\left(\mathrm{Mn}^{+2}\right)$ and iron $\left(\mathrm{Fe}^{+3}\right)$ were measured by using ICPOES Model Varian lab Liberty Series II.

\section{Bacteriological analysis}

Collected samples were examined within 6 hours followed the method from Standard book for Examination of Water and Wastewater (APHA, 2012). According to standard method Nos. 9222B, 9222 D total coliforms (TC), fecal coliforms (FC) and fecal streptococci (FS), using membrane filter technique. All media were obtained form Difco-USA. Results were recorded as colony forming unit ( $\mathrm{cfu} 100 \mathrm{ml}^{-1}$ ) by using equation:

$$
\text { Colonies } / 100 \mathrm{ml}=\frac{\text { Counted colonies }}{\mathrm{ml} \text { of sample filtered }} \times 100
$$

\section{Factors effect on the NPs antibacterial activityTemperature effect}

CuO-TOAB was used at $10^{2}$ and $10^{3}$ concentrations by $\mu \mathrm{g} / \mathrm{mL}$. Samples could be control shaking at $150 \mathrm{rpm}$ for $2 \mathrm{~h}$ at $15,25,35^{\circ} \mathrm{C}$. 


\section{Contact time effect}

Preparing of $\mathrm{CuO}-\mathrm{TOAB}$ NPs at $75^{\circ} \mathrm{C}$. Using $\mathrm{CuO}-\mathrm{TOAB}$ is better activity. studying carried out concentrations; $10^{2}$ and $10^{3} \mu \mathrm{g} / \mathrm{mL}$ of $\mathrm{CuO}-$ TOAB. We must control some paramters such as shaking at $150 \mathrm{rpm}$ for $24 \mathrm{~h}$ at $25^{\circ} \mathrm{C}$.

\section{Testing Flow}

Preparing $\mathrm{CuO}$ NPs is important for water treatment, testing flow using to investigate the antibacterial activity of $\mathrm{CuO}$ NPs .Increasing application of preparing $\mathrm{CuO}$ NPs for water treatment. Sterile column (L: $44 \mathrm{X} \mathrm{D}: 12 \mathrm{~mm}$ ) used to flow $4.00 \mathrm{~mL}$ of drainage water. Thickness of $\mathrm{CuO}-\mathrm{TOAB}$ layer about $1.0 \mathrm{~mm}$. flow rate of $10 \mathrm{~mL} / \mathrm{min}$ was constant . E. faecalis bacteria and TC.

\section{DNA extraction and library preparation}

All collected water samples were stirring for $10 \mathrm{~min}$ at $6000 \mathrm{~g}$ to be concentrated.Filtration using A $0.22 \mu \mathrm{m}$ filter injection found structure of microbiome and pathogens. Using $250 \mathrm{mg}$ of pellets for DNA extraction. DNA could be isolated (MoBio, USA (Kaevska et al., 2011). using gel electrophoresis was detect DNA quality. Fluorometer (Thermo, USA) finding out quantity of DNA.. Illumina HiSeq 2000 using conducted at the Colors Company, Egypt.

DNA exctraction was diluted to $200-300 \mathrm{ng} / \mu \mathrm{L}$, for using experimental (Ali et al., 2019a). The procedure of DNA library related to Campanaro et al.,2016. The short reads were fragmented by a minimum 30 quality score. no ambiguous nucleotides. parameters were get overlapping about 20 nucleotide length of region was needed. (Ali et al., 2019b).

\section{Metagenomic determine}

A prediction for metagenomic computational of DNA was utilized from the international of National Center for Biotechnology Information (NCBI). Prediction server given the metabolic and taxonomic affiliation. analyzing protein as reported (Meyeret al., 2008). About $10^{-5} \mathrm{E}$ value for investigation taxonomic enrollment on MG-RAST (Huson et al., 2011). Capacity of taxonomic as phyla, and genus, was determined for explanation. Hierarchical divide to at $\mathrm{E}$ value deducation of $10^{-5}$ using for gene comments on profile (Yang et al., 2014). The gentics were divided successfully into hierarchical metabolic groups. Entering reads were decoded across the bibliography of the Kyoto Encyclopedia of Genes and Genomes (KEGG) databases.

\section{Bioinformatic analysis}

Sequences of DNA were identified using Basic Local Alignment Search Tool (blast) on the NCBI database. Using DNAMAN software 
performed for many alignments of sequences (Madison, Wisconsin, USA, version 5.2.9). (Thompson et al., 1994). The nucleotide distances were measured alignment gaps and using Juckes and Cantor's method (Jukes and Cantor, 1969). Development of Molecular Genetic Analysis (MEGA) software (version 6.0) (Tamura et al., 2013).

Identification for Relationship of Phylogenetic between microbial community. Evaluaion using unweighting two Method with Arithmetic Mean (UPGMA) through MEGA 6.0 software. and boot strap analysis (1000 replicates) was performed to assess the reliability of the constructed phylogenetic. Nucleotide sequences data determined by the National Center for Biotechnology Information (NCBI) GenBank database, USA.

\section{Statistical analysis}

Data mean values and percentages were calculated using Minitab 16 statistical software program (Minitab, 2010).

\section{RESULTS AND DISCUSSION \\ Eco-diversity of collected water samples}

The process quality of water is an evaluation of physical, chemical and biological nature of water .Quality of water may effect ont human health and health of the aquatic system . Our area of study, water quality drains was carried out. The results obtained from physical, chemical, microbial community, calculating parameters and statistical analyses. investigation, both of $\mathrm{pH}$, turbidity, $\mathrm{DO}, \mathrm{BOD}$ and COD concentrations showed variable results according to site nature of pollution. in Figure 1(A \& B). water samples collected from drains outlets showed high turbidity, marked depletion in DO values and all COD concentrations exceeded law 48. The maximum values were at El- Rahawy, Sabal and Tala drains while. Minimum values were at Zawiet El-bahr and ElTahreer drains.

Water quality of drains outlets was improved after treated with by $\mathrm{CuO}$ nanoparticles with different percentages especially in water turbidity (67\%), DO (43.2\%), BOD (85\%) and COD (85\%). Organic matter concentrations play the important role in water quality and related stronglywith microbial load in aquatic system. $\mathrm{CuO}$ nanoparticles used as antibacterial material in many studies which confirmed the ability of this particles for bacterial indicators degradations. Suleiman et al., 2013, prepared and apply $\mathrm{CuO}$ nanoparticles in bacterial indicators degradation (TC, FC and FS) and microbial removing with concentration less than $1000 \mu \mathrm{g} / \mathrm{mL}$. 

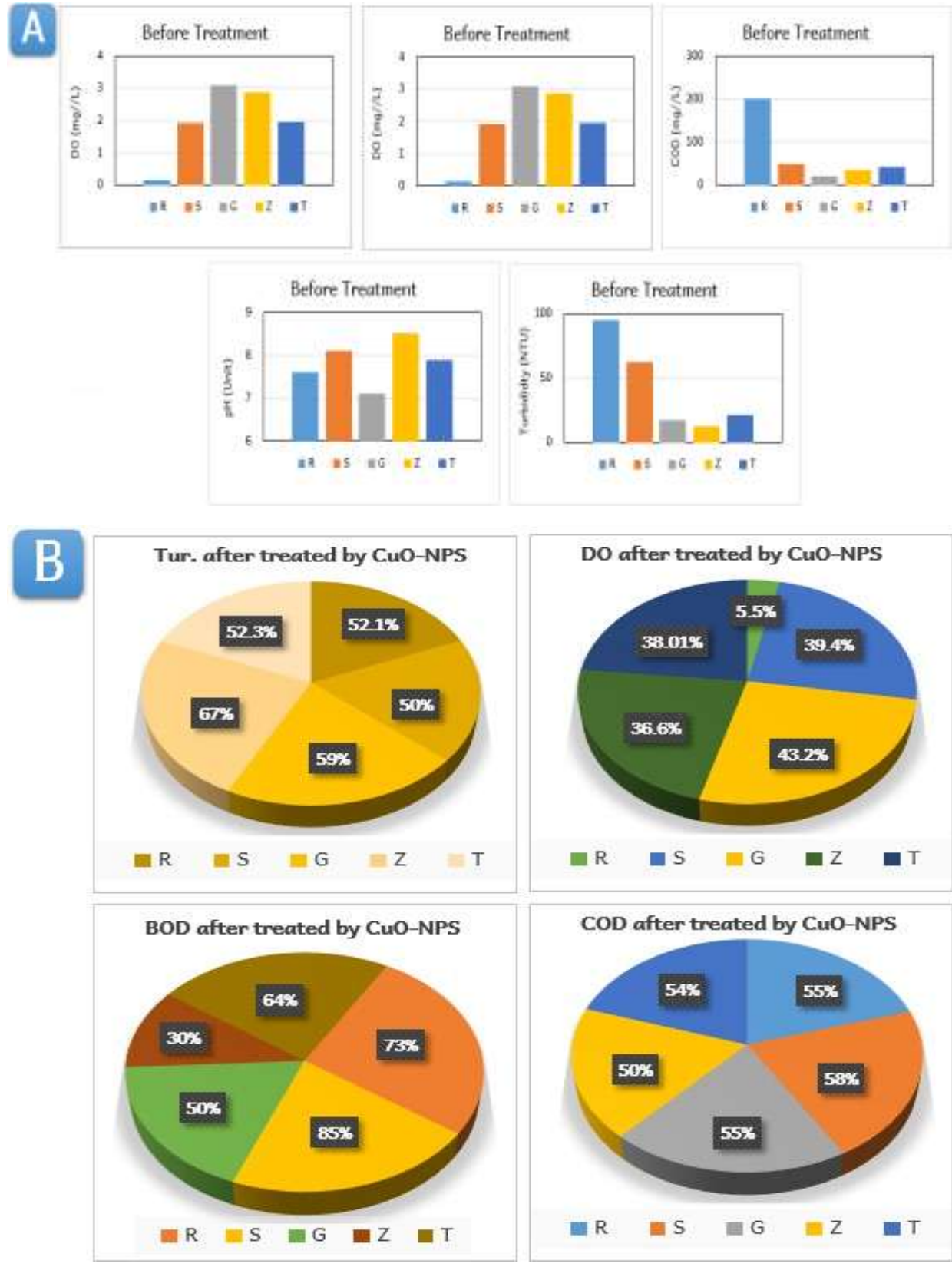

Figure 1. Physicochemical properties of collected water samples

A. $\mathrm{pH}$, turbidity, $\mathrm{DO}, \mathrm{BOD}, \mathrm{COD}$ values before treatment with $\mathrm{CuO}$ nanoparticles.

B. Improvement percentage after treatment with $\mathrm{CuO}$ nanoparticles. 


\section{Different factors effect on NPs antibacterial activity}

Assessment for water quality process is an assessed of physical, chemical and biological nature of water ., This process effecsts human health and health of aquatic system.

$\mathrm{CuO}$ NPs were prepared with and without TOAB surfactant. It investigatedin a real drainage water samples. Many parameters that may affect the antibacterial activity. We taked the optimum conditions to have NPs with high activity used in drainage water disinfectant.

The most factors affecting bacterial growth in aquaticenvironment is Temperature. Weather of Palestine that temperature almost range from $10-35^{\circ} \mathrm{C}$. Areflection of the slow water response to the weather temperature. Different incubation effect on temperature; 15,25 and $35^{\circ} \mathrm{C}$, were studied a factor in antibacterial activity of $\mathrm{CuO}$ NPs at concentration $\left(10^{2} \mu \mathrm{g} / \mathrm{mL}\right)$.

Studying area antibacterial activity of $\mathrm{CuO}$ NPs was studied at different contact time of $0,1,2$ and $24 \mathrm{hr}$ at $25^{\circ} \mathrm{C}$. Determination appropriate contact time. Studingfor five samples and our results showed the best concentration $\left(10^{2} \mu \mathrm{g} / \mathrm{mL}\right)$ of drainage watersamples were 90,92 , 95, 96, 98\%.

Testing flow at fixed flow rate of $10 \mathrm{~mL} / \mathrm{min}$ was cleared antibacterial $\mathrm{CuO}$ NPs. This study needed optimum conditions to investigation such as pHand temperature. Degradation of bacteria percent reach to $99 \%$. Indicators of bacteria using in drainage water samples passing $\mathrm{CuO}-\mathrm{TOAB}$. Drainage water samples passing $\mathrm{CuO}$ nonstabilized. Percent degradation for E.faecalis bacterial and TC were 79, $83,75,89$ and $81 \%$, successively . CuO NPs stabilized with TOAB is enable effective degradation of bacteria than using $\mathrm{CuO}$ NPs without stabilization.

\section{Biodiversity of Microbial Community}

About 35 thousand active sequences abundant quality were collected for evaluation. Homogeneous sequences with different quantities were found in about four parts of drain Zawiet El-Bahr. Concentration comparative active steps was evaluated in studying (Kaevska etal., 2016 and Azzam et al., 2017). Quantity of microbes is high.Viruses was get in both of El-Rahawy and Sabal drain outlet. Fewer in Tala and El-Tahreer drain outlet . Figure 1. The sewage sample was reported 1730 species where agriculture drain about 1490 species was discovered in class-level classification. Ye and co-authors reported a similar finding when studding wastewater samples (Ye and Zhang, 2013). In accordance some studied from researches noticed diversification were higher in domestic drains when comparison with agriculture drains (Lee et al., 2015). Data agreement to our investigation to statistical data. Mixing domestic and agricultural drains samples were 
found like samples from agricultural drainsas reported from statically analysis. Similar variance in the microbial structure founded in ElRahawy drain (R), Sabal drain (S), El-Tahreer drain (E) drain, Zawiet ElBahr drain (Z) and Tala drain (T).

Bacteria represent the most percent in domestic drains with $97.2 \%$ specially in El-Rahawy, Sabal and Tala drains. Concentration ratio of archaea, eukaryote, and viruses was measured in the five drains. publishing studies reported a similar Concentration (Yang et al., 2014).

In El-Rahawy drain the concentration of viruses, accounting $5.82 \%$,was about three times higher than the other drains. A smaller bacterial concentration. Analysis details in Figure 2.

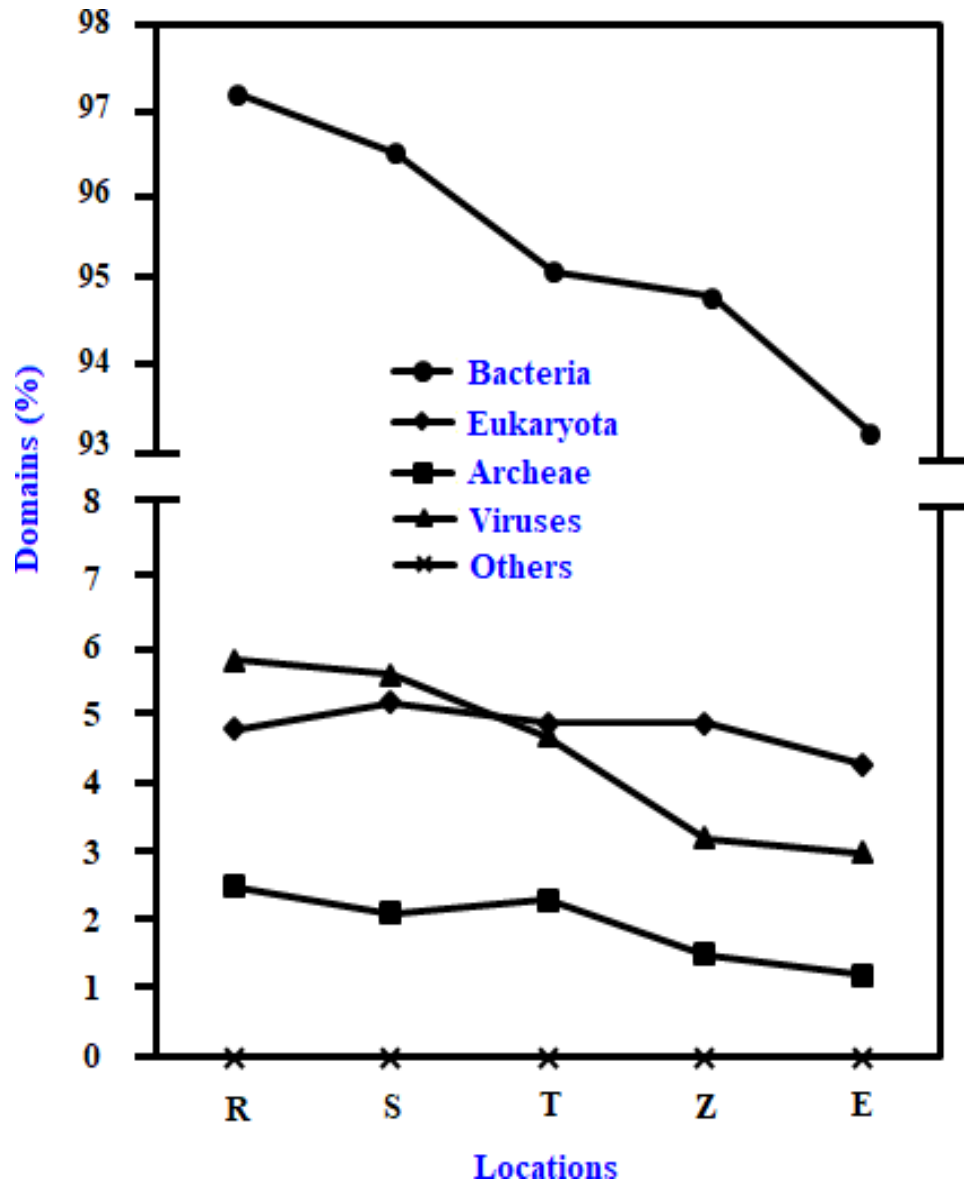

Figure (2): Taxonomic profiling at the domain level of the studied Egyptian five mixed drains. sequences of DNA were assigned to bacteria, eukaryote, archaea, viruses, other sequences. 
Detecting the whole microbial structure and also the functional profiling of the (DS) digestion sludge, data were showed in Figure 3. represented short reading where analyzed according to the KEGG category database.

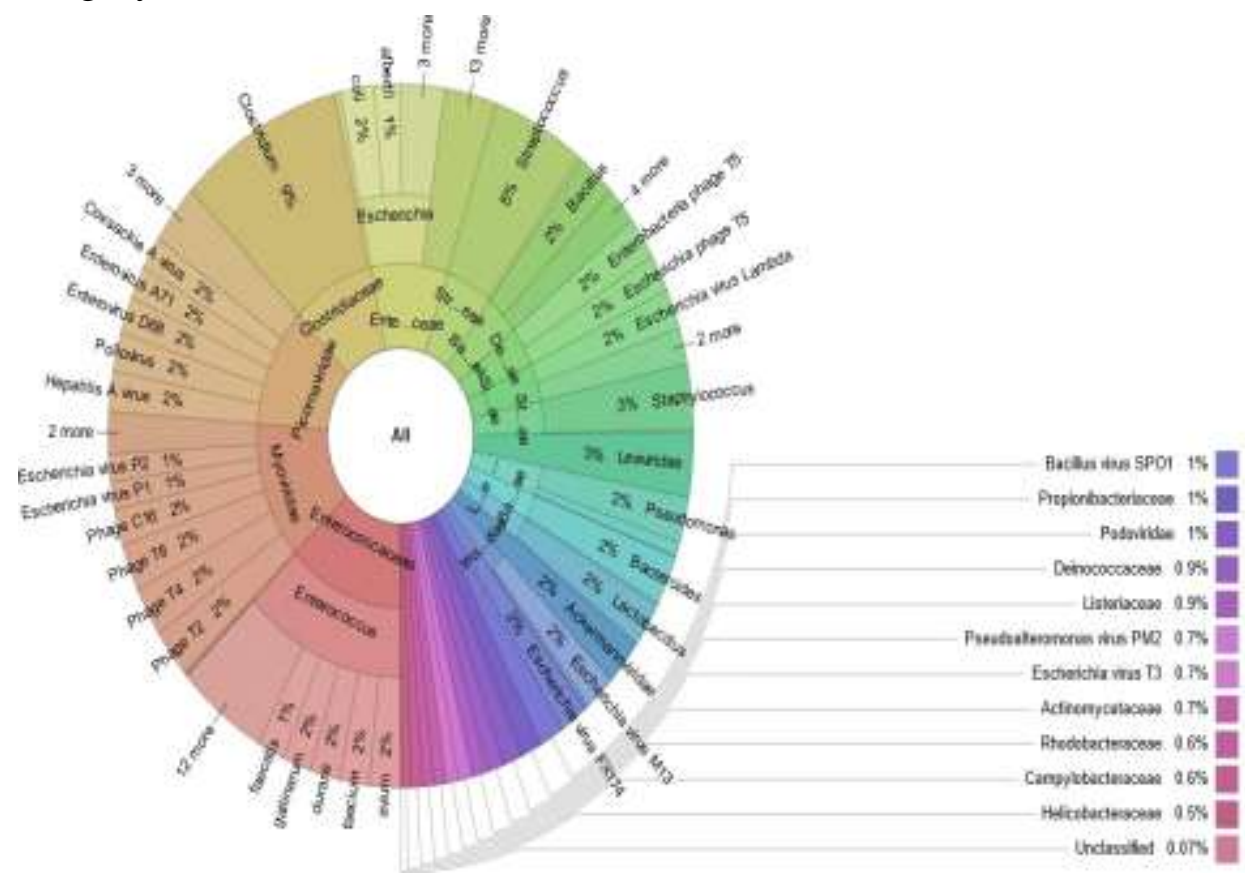

Figure 3. Krona taxonomy chart for all bacterial and viral strains discovered in water samples.

In the sewage drains outlets the precent of phyla Proteobacteria, Bacteroidetes, Firmicutes-associated bacteria were the highest, , as shown in Table 1.

The founded results were correlated to previous report which reported by Lee's group (Lee et al. 2015). In agreement with our results a high number of Actinobacteria were found as reported by McLellan's group (McLellan et al., 2010). Delta-proteobacteria and alpha beta (Table 1). Significant concentration reporting in all outlets domestic presented Epsilon and Gamma proteobacteria less concentration. Lee and co-authors proving agreement investigation (Lee et al. 2015).

Previous reports reported that Gamma-proteobacteria, Deinococcus and Clostridiales were dominant classes (Ye and Zhang 2013). Parameters difference may cause a variance in microbial composition of aquatic systems. climate zones, industry, agriculture wastes and human activity (McLellan et al. 2010). 
Table 1: Dominant precent class in major phylum from bacteria and archaea found inwater samples.

\begin{tabular}{|c|c|c|c|c|c|c|}
\hline Phylum & Class & $\begin{array}{c}\mathbf{R} \\
\text { Abundance (\%) }\end{array}$ & $\begin{array}{c}\mathbf{S} \\
\text { Abundance } \\
(\%)\end{array}$ & $\begin{array}{c}\mathbf{T} \\
\text { Abundance } \\
(\%)\end{array}$ & $\begin{array}{c}\mathbf{Z} \\
\text { Abundance } \\
(\%)\end{array}$ & $\begin{array}{c}\mathbf{G} \\
\text { Abundance } \\
(\%)\end{array}$ \\
\hline \multirow[t]{5}{*}{ Proteobacteria } & Alphaproteobacteria & 26 & 22.1 & 19.2 & 17.3 & 15.4 \\
\hline & Betaproteobacteria & 26.3 & 21.9 & 19.3 & 17.1 & 15.4 \\
\hline & Gammaproteobacteria & 26.5 & 21.6 & 19.5 & 17.3 & 15.1 \\
\hline & Epsilonproteobacteria & 25.9 & 22.2 & 19.3 & 17.4 & 15.2 \\
\hline & Others & 26.7 & 18.1 & 24.9 & 13.1 & 17.2 \\
\hline \multirow[t]{2}{*}{ Actinobacteria } & Actinobacteria & 27 & 23 & 19 & 17 & 14 \\
\hline & Others & 0.50 & 0.41 & 0.30 & 0.24 & 0.19 \\
\hline \multirow[t]{2}{*}{ Bacteroidetes } & Bacteroidia & 32 & 26 & 17.1 & 14.4 & 10.5 \\
\hline & Others & 1.90 & 1.86 & 1.90 & 1.80 & 1.65 \\
\hline \multirow[t]{2}{*}{ Deinococcus } & Deinococci & 28 & 22.8 & 16 & 12 & 8 \\
\hline & Others & 6.40 & 5.87 & 6.02 & 3.60 & 4.01 \\
\hline \multirow[t]{3}{*}{ Firmicutes } & Bacilli & 20 & 20 & 19 & 13 & 15 \\
\hline & Clostridia & 45 & 39 & 32 & 21 & 28 \\
\hline & Erysipelotrichia & 2.01 & 2.01 & 1.99 & 1.67 & 1.50 \\
\hline
\end{tabular}

In El-Rahawy, Sabal and Tala drain outlets a high concenteration of viruses with percent $8 \%$ while less concentration was found in ElTahreer, Zawiet El-Bahar drains of samples. Some studies detected a small concentration of viruses in their investigation (Hu, 2012 and Safaa and Azzam, 2020).

A high concentration of Proteobacterial and virus's classes to clostridia, actinomycetes, Bacteriodes, Deinococcus and Firmicutes were reported in the sewage drains when comparing to another drains Figure 3. Several species which belonging to strain Pseudomonades causing opportunistic disease agents in some humans, plants and animals.

Firmicutes strains are deathly to humans and plants and also Closteridia species are pathogens which causing some effects to humans, animals (Godoy et al., 2003). Bifdobacterium considered as Grampositive and branching. anaerobic bacteria are wide speed in their inhabitants as gastrointestinal tract and mouth of mammals such as humans (Schell et al., 2002; Mayo and Sinderen 2010). To understand the complete microbiota of all parts in the drain outlets the species -level classification was applied. many species as Staphylococcus, Salmonella, Shigella, Pseudomonas were found to be in an enhanced concentration in domestic drains outlets along the Rosetta branch as compared with the industrial and agricultural drains samples, in Figure 4.

In some publishing literature the same concentration of species was discussed (Ye and Zhang 2013). aFish technology were conducting by some researchers to input Actinobacteria and Betaproteobacteria are primary bacterial in domestic drains and surface water (Muszynski et al., 2015). About 38\% of the strains were existing in the river Nile. Several Publishing research decide the presence of Betaproteobacteria and Gammaproteobacteria in samples of activate sludge (Kwon et al., 2010). 


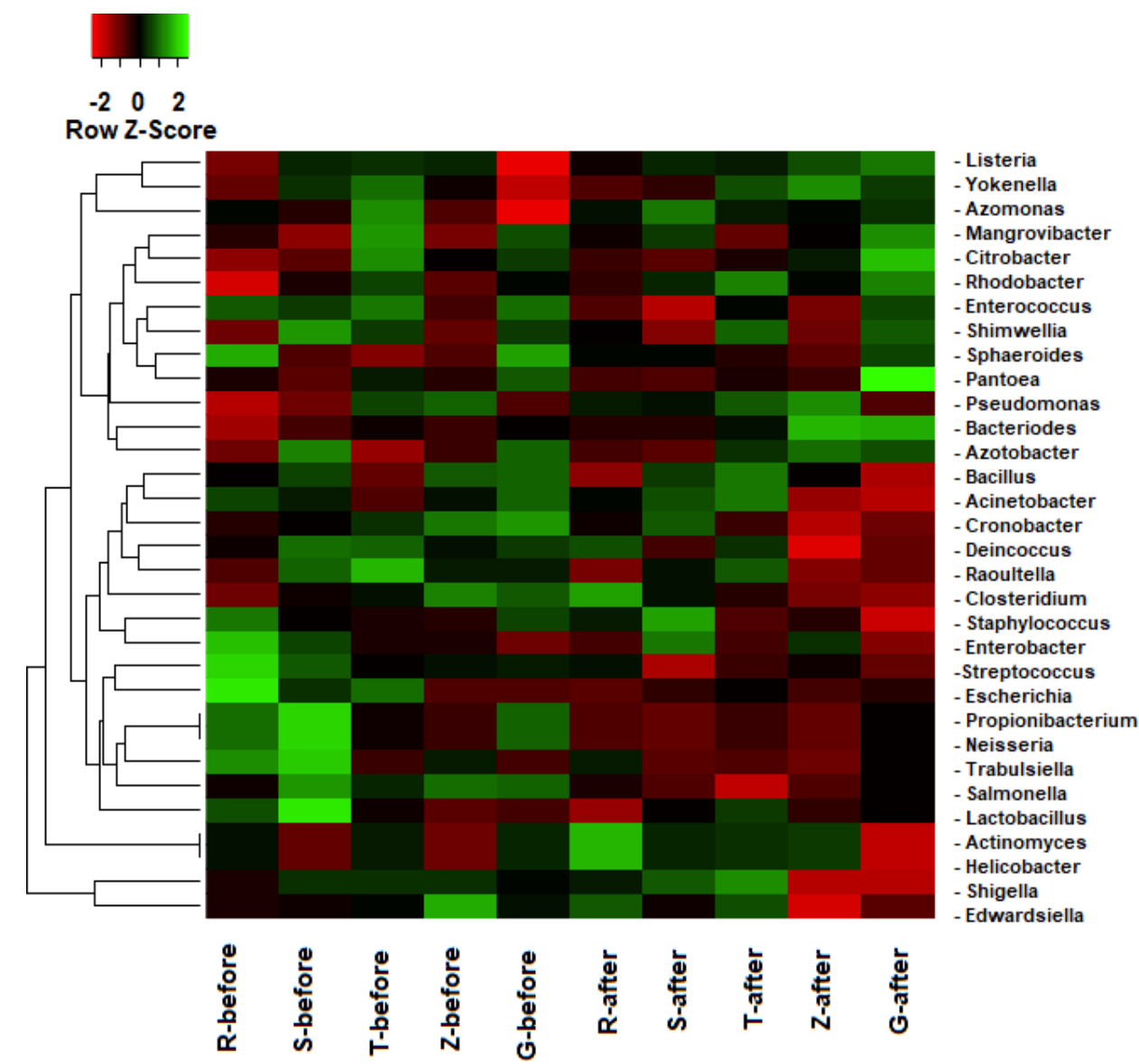

Figure 4. Heat map and genetic distance for novel bacterial species discovered in water samples.

Many of bacterial structure in drains outlets depending locality, source of pollution, water effluent, and long of the drains effects the evaluation and removing capacity of microbial pathogens. Enormous investigation under process dependence cofactor differences of the bacterial community was behaved (Helbling et al., 2015; Johnson et al., 2015). bacterial species range existing in mixed drains and agricultural drains. critical role in the nanoparticle size.Method treatment for water reporting of many researchers (Hu et al., 2012).

Dominant steps reporting in the case study belonge to the phylum Proteobacteria and no effect in drains outlets. Case study proving interesting discovery for a comprehensive pathogenic detection and removal in various stages along the drains. The domestic drains both of 
industrial and agricultural drains. samples had like composition; a less concentration of Actinobacteria species was reported.

Variety and causing diseases of domestic drain were reported to be higher in comparison with other types of samples (Figure 5). Result revealed that the self- purification and precipitation steps is not complete entirely, microbiota exists in the drains outlets. Transferring in the surface water. Observing in agreement with beforehand publishing. Concentration of pathogenic species as Actinobacter and Salmonella species effects (Bibby et al. 2010; Ye and Zhang 2013). Using Illumina sequencing technology in casing study proved a potential method to measured pathogenic microbes.

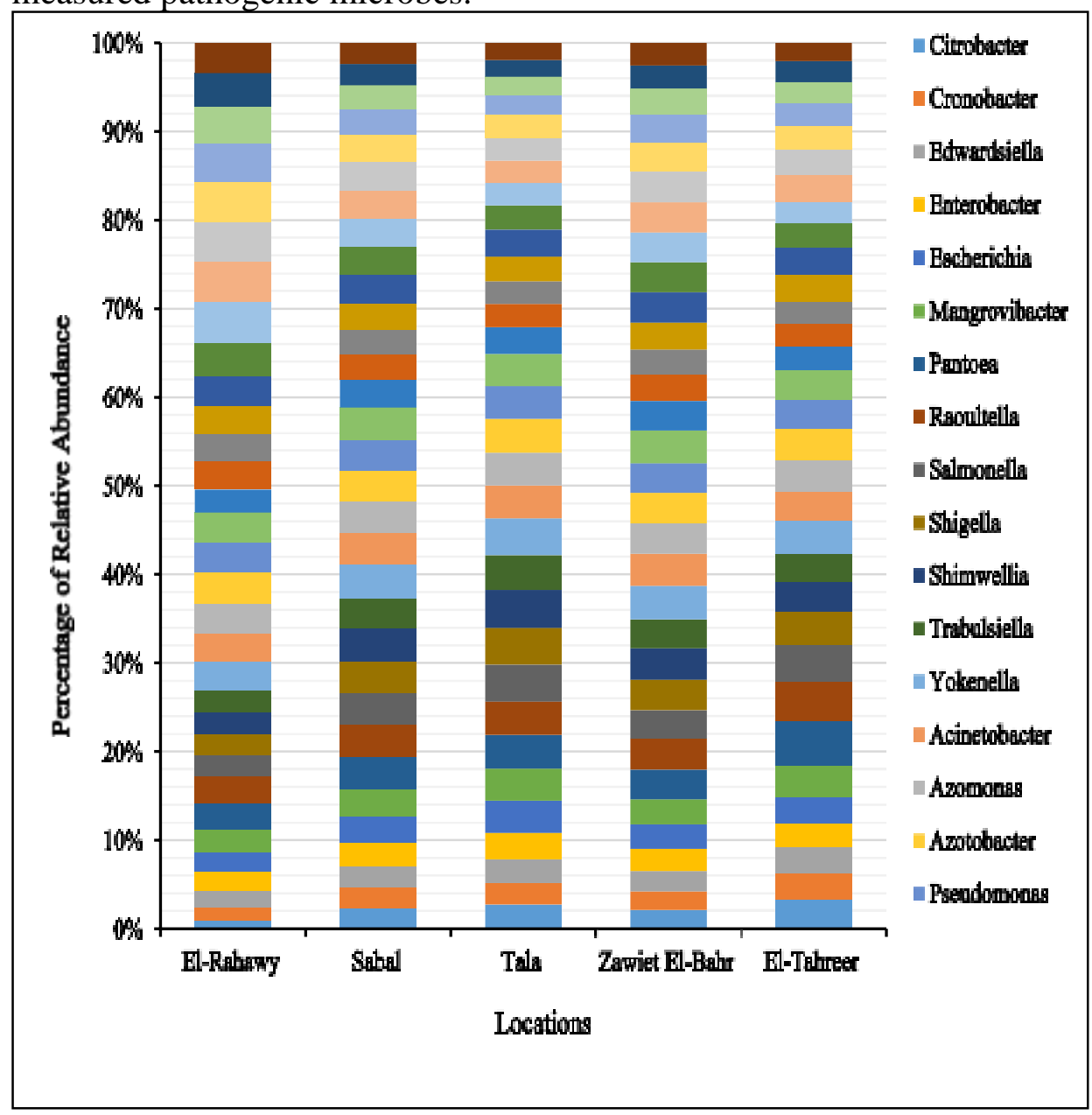

Figure 5. Abundance of microbial community in drainage water before treatment by $\mathrm{CuO}$ nanoparticles. 


\section{CONCLUSIONS}

The synthesized $\mathrm{CuO}$ NPs by a rapid precipitation method in absence and presence of (TOAB). Using a stabilizer to control nanoparticles size. $\mathrm{CuO}$ NPs was tested to examine their antibacterial activity using (TC), (FC) and (E. faecalis) bacteria in wastewater samples. several parameters were evaluated to having the optimum wastewater disinfection factors, as nanoparticles concentration, and temperature, contact period, $\mathrm{pH}$ value, shaking conditions of wastewater. High antibacterial activity appeared from CuO-TOAB stabilized NPs more than without TOAB surfactant. the antibacterial activity of both $\mathrm{CuO}$ NPs has slightly effect by the Contact period, where high activity of $\mathrm{CuO}$ happened in wastewater samples when were treated at $25^{\circ} \mathrm{C}$ and $35{ }^{\circ} \mathrm{C}$, respectively. Noticed that, decreasing the $\mathrm{pH}$ values The antibacterial activity of $\mathrm{CuO}$ increasing. When shaking conditions increase from 70 and $90 \%$ the activity of $\mathrm{CuO}$ NPs affect. Positive bacteria E. fecals more effects than gram negative (TC and FC) by studied conditions. Using a novel technique using for wastewater. Including Ilumina sequencing technology is a potential and robust way to investigate microbial structure. In future we could remove and eliminate the pathogens from the wastewater treatment process. Illumina sequencing technology detect disease-causing agents in wastewater.

\section{ACKNOWLEDGEMENT}

We would like to thank the staff of micro lab and inorganic lab for Central Laboratory for Environmental Quality Monitoring (CLEQM) for their cooperation during measurement for the work.

\section{REFERENCES}

Aird, D. ; M.G. Ross ; W.S. Chen; M. Danielsson ; T. Fennell ; C. Russ and A. Gnirke (2011). Analyzing and minimizing PCR amplification bias in Illumina sequencing libraries. Genome Biology, 12(2): 1-14.

Albertsen, M. ; L.B.S. Hansen ; A.M. Saunders ; Nielsen P.H. and K.L. Nielsen (2006). A metagenome of a full-scale microbial community carrying out enhanced biological phosphorus removal. ISME J., 6(6):1094-1106.

Ali, N. ; H. Gong; A.S. Giwa; Q. Yuan and K. Wang (2019). Metagenomic analysis and characterization of acidogenic microbiome and effect of $\mathrm{pH}$ on organic acid production. Archives of Microbiology, 201(9): 1163-1171. 
Ali, N. ; H. Gong ; X. Liu ; A.S. Giwa and K. Wang (2020). Evaluation of bacterial association in methane generation pathways of an anaerobic digesting sludge via metagenomic sequencing. Arch Microbiol,202(1):31-41.

APHA, (2012): American Public Health Association (APHA) and American Water Works Association and Water Environment Federation,. Standard Methods for the Examination of Water and Wastewater, 22 ${ }^{\text {nd }}$ edition. American Public Health Association, Washington, DC.

Anandan, S. ; G.J. Lee and J.J. Wu (2012). Sonochemical synthesis of $\mathrm{CuO}$ nanostructures with different morphology. Ultrasonics Sonochemistry, 19(3): 682-686.

Azzam, M.I. ; S.M. Ezzat ; B.A. Othman and K.A. El-Dougdoug (2017). Antibiotics resistance phenomenon and virulence ability in bacteria from water environment. Water Science, 31(2): 109-121.

Bibby, K. ; E. Viau and J. Peccia (2010). Pyrosequencing of the $16 \mathrm{~S}$ rRNA gene to reveal bacterial pathogen diversity in biosolids. Water Research, 44(14): 4252-4260.

Bragg, L. and G.W. Tyson (2014). Metagenomics using next-generation sequencing. In: Paulsen IT, Holmes AJ (eds) Environmental microbiology: methods and protocols, methods in molecular biology, vol 1096, 2nd edn. Humana Press, New York, pp 183-201.

Campanaro, S. ; L. Treu ; P.G. Kougias ; D. De Francisci ; G. Valle and I. Angelidaki (2016). Metagenomic analysis and functional characterization of the biogas microbiome using high throughput shotgun sequencing and a novel binning strategy. Biotechnology for Biofuels, 9(1): 1-17.

Cann, K.F. ; D.R. Thomas ; R.L. Salmon ; A.P. Wyn-Jones and D. Kay (2013). Extreme water-related weather events and waterborne disease. Epidemiology \& Infection, 141(4): 671-686.

Chang, Y. and H.C. Zeng (2004). Controlled synthesis and selfassembly of single-crystalline $\mathrm{CuO}$ nanorods and nanoribbons. Crystal Growth \& Design, 4(2): 397-402.

Da Silva, L.M. ; D.V. Franco ; I.C. Gonçalves and L.G. Sousa (2009). Advanced technologies based on ozonation for water treatment. Water Purification, 1-53.

De Giglio, O. ; G. Barbuti ; P. Trerotoli ; S. Brigida ; A. Calabrese ; G. Di Vittorio and M.T. Montagna (2016). Microbiological and hydrogeological assessment of groundwater in southern Italy. Environmental Monitoring and Assessment, 188(11): 1-9. 
Ezzat, S.M. and M.I. Azzam (2020). An approach using a novel phage mix for detecting Pseudomonas aeruginosa in water. Water and Environment Journal, 34(2): 189-202.

Fierer, N. and R.B. Jackson (2006). The diversity and biogeography of soil bacterial communities. Proceedings of the National Academy of Sciences, 103(3): 626-631.

Gao, P. ; W. Xu ; P. Sontag ; X. Li ; G. Xue ; T. Liu and W. Sun (2016). Correlating microbial community compositions with environmental factors in activated sludge from four full-scale municipal wastewater treatment plants in Shanghai, China. Applied Microbiology and Biotechnology, 100(10): 4663-4673.

Glenn, T.C. (2011). Field guide to next-generation DNA sequencers. Molecular Ecology Resources, 11(5): 759-769.

Godoy, D. ; G. Randle ; A.J. Simpson ; D.M. Aanensen ; T.L. Pitt ; R. Kinoshita and B.G. Spratt (2003). Multilocus sequence typing and evolutionary relationships among the causative agents of melioidosis and glanders, Burkholderia pseudomallei and Burkholderia mallei. Journal of Clinical Microbiology, 41(5): 2068-2079.

Helbling, D.E. ; D.R. Johnson ; T.K. Lee ; A. Scheidegger and K. Fenner (2015). A framework for establishing predictive relationships between specific bacterial 16S rRNA sequence abundances and biotransformation rates. Water Research, 70: 471-484.

Hu, M. ; X. Wang ; X. Wen and Y. Xia (2012). Microbial community structures in different wastewater treatment plants as revealed by 454-pyrosequencing analysis. Bioresource Technology, 117: 72-79.

Hunter, P.R. ; J.M. Colford ; M.W. LeChevallier ; S. Binder and P.S. Berger (2001). Waterborne diseases. Emerging Infectious Diseases, 7(3 Suppl), 544.

Huson, D.H. ; S. Mitra ; H.J. Ruscheweyh ; N. Weber and S.C. Schuster (2011). Integrative analysis of environmental sequences using MEGAN4. Genome research, 21(9): 1552-1560.

Johnson, D.R. ; T.K. Lee ; J. Park ; K. Fenner and D.E. Helbling (2015). The functional and taxonomic richness of wastewater treatment plant microbial communities are associated with each other and with ambient nitrogen and carbon availability. Environmental Microbiology, 17(12): 4851-4860. 
Ju, F. ; F. Guo ; L. Ye ; Y. Xia and T. Zhang (2014). Metagenomic analysis on seasonal microbial variations of activated sludge from a full-scale wastewater treatment plant over 4 years. Environmental Microbiology Reports, 6(1): 80-89.

Jukes, T.H. and C.R. Cantor (1969). Evaluation of Protein Molecules. In: Mammalian Protein Metabolism, Munro, H.N. (Ed.) Academic Press, New York, pp. 21-132.

Kaevska, M. ; I. Slana ; P. Kralik ; U. Reischl ; J. Orosova ; A. Holcikova and I. Pavlik (2011). "Mycobacterium avium subsp. hominissuis" in neck lymph nodes of children and their environment examined by culture and triplex quantitative realtime PCR. Journal of Clinical Microbiology, 49(1): 167-172.

Kaevska, M. ; P. Videnska and P. Vasickova (2016). Changes in microbial composition of wastewater during treatment in a fullscale plant. Current microbiology, 72(2): 128-132.

Khan, N.H. ; Y. Ishii ; N. Kimata-Kino ; H. Esaki ; T. Nishino ; M. Nishimura and K. Kogure (2007). Isolation of Pseudomonas aeruginosa from open ocean and comparison with freshwater, clinical, and animal isolates. Microbial Ecology, 53(2): 173-186.

Kwon, S.D. ; T.S. Kim ; G.H. Yu ; J.H. Jung and H.D. Park (2010). Bacterial community composition and diversity of a full-scale integrated fixed-film activated sludge system as investigated by pyrosequencing. Journal of Microbiology and Biotechnology, 20(12): 1717-1723.

La Rosa, G. ; M. Pourshaban ; M. Iaconelli and M. Muscillo (2010). Quantitative real-time PCR of enteric viruses in influent and effluent samples from wastewater treatment plants in Italy. Annali Dell'istituto Superiore Di Sanita, 46: 266-273.

Lee, S.H. ; H.J. Kang and H.D.Park (2015). Influence of influent wastewater communities on temporal variation of activated sludge communities. Water Research, 73: 132-144.

Li, A. ; Y.N. Chu ; X. Wang ; L. Ren ; J. Yu ; X. Liu and S. Li (2013). A pyrosequencing-based metagenomic study of methane-producing microbial community in solid-state biogas reactor. Biotechnology for Biofuels, 6(1): 1-17.

Mackelprang, R. ; M.P. Waldrop ; K.M. DeAngelis ; M.M. David ; K.L. Chavarria ; S.J. Blazewicz and J.K. Jansson (2011). Metagenomic analysis of a permafrost microbial community reveals a rapid response to thaw. Nature, 480(7377): 368-371. 
Mardis, E.R. (2008). The impact of next-generation sequencing technology on genetics. Trends in genetics, 24(3): 133-141.

Mason, O.U. ; N.M. Scott ; A. Gonzalez ; A. Robbins-Pianka ; J. Bælum ; J. Kimbrel and J.K. Jansson (2014). Metagenomics reveals sediment microbial community response to Deepwater Horizon oil spill. The ISME Journal, 8(7): 1464-1475.

Mayo, B. and D. Van Sinderen (2010). Bifidobacteria: genomics and molecular aspects. Horizon Scientific Press.

McLellan, S.L. ; S.M. Huse ; S.R. Mueller-Spitz ; E. N. Andreishcheva and M.L. Sogin (2010). Diversity and population structure of sewage-derived microorganisms in wastewater treatment plant influent. Environmental Microbiology, 12(2): 378-392.

Meyer, F. ; D. Paarmann ; M. D'Souza ; R. Olson ; E.M. Glass ; M. Kubal and R.A. Edwards (2008). The metagenomics RAST server-a public resource for the automatic phylogenetic and functional analysis of metagenomes. BMC bioinformatics, 9(1): 1-8.

Minitab, (2010). Minitab 16 Statistical Software. Minitab Inc., State College, Pennsylvania, USA.

Muszyński, A. ; A. Tabernacka and A. Miłobędzka (2015). Long-term dynamics of the microbial community in a full-scale wastewater treatment plant. International Biodeterioration \& Biodegradation, 100: 44-51.

Odjadjare, E.E. ; E.O. Igbinosa ; R. Mordi ; B. Igere ; C.L. Igeleke and A.I. Okoh (2012). Prevalence of multiple antibiotics resistant (MAR) Pseudomonas species in the final effluents of three municipal wastewater treatment facilities in South Africa. International Journal of Environmental Research and Public Health, 9(6): 2092-210.

Radomski, N. ; L. Betelli ; R. Moilleron ; S. Haenn ; L. Moulin ; E. Cambau and F.S. Lucas (2011). Mycobacterium behavior in wastewater treatment plant, a bacterial model distinct from Escherichia coli and enterococci. Environmental science \& technology, 45(12): 5380-5386.

Rehman, S. ; A. Mumtaz and S.K. Hasanain (2011). Size effects on the magnetic and optical properties of $\mathrm{CuO}$ nanoparticles. Journal of Nanoparticle Research, 13(6): 2497-2507.

Ren, G. ; D. Hu ; E.W. Cheng ; M.A. Vargas-Reus ; P. Reip and R.P. Allaker (2009). Characterisation of copper oxide nanoparticles for antimicrobial applications. International Journal of Antimicrobial Agents, 33(6): 587-590. 
Sánchez, O. ; I. Ferrera ; J.M. González and J. Mas (2013). Assessing bacterial diversity in a seawater-processing wastewater treatment plant by 454-pyrosequencing of the $16 \mathrm{~S}$ rRNA and amoA genes. Microbial Biotechnology, 6(4): 435-442.

Savichtcheva, O. and S. Okabe (2006). Alternative indicators of fecal pollution: relations with pathogens and conventional indicators, current methodologies for direct pathogen monitoring and future application perspectives. Water Research, 40(13): 2463-2476.

Schell, M.A. ; M. Karmirantzou ; B. Snel ; D. Vilanova ; B. Berger ; G. Pessi and F. Arigoni (2002). The genome sequence of Bifidobacterium longum reflects its adaptation to the human gastrointestinal tract. Proceedings of the National Academy of Sciences, 99(22): 14422-14427.

Stephenson, F.H. (2016). Calculations for molecular biology and biotechnology. Academic press.

Suleiman, A.K.A. ; L. Manoeli ; J.T. Boldo ; M.G. Pereira and L.F.W. Roesch (2013). Shifts in soil bacterial community after eight years of land-use change. Systematic and Applied Microbiology, 36(2): 137-144.

Sundberg, C. ; W.A. Al-Soud ; M. Larsson ; E. Alm ; S.S. Yekta ; B.H. Svensson and A. Karlsson (2013). 454 pyrosequencing analyses of bacterial and archaeal richness in 21 full-scale biogas digesters. FEMS Microbiology Ecology, 85(3): 612-626.

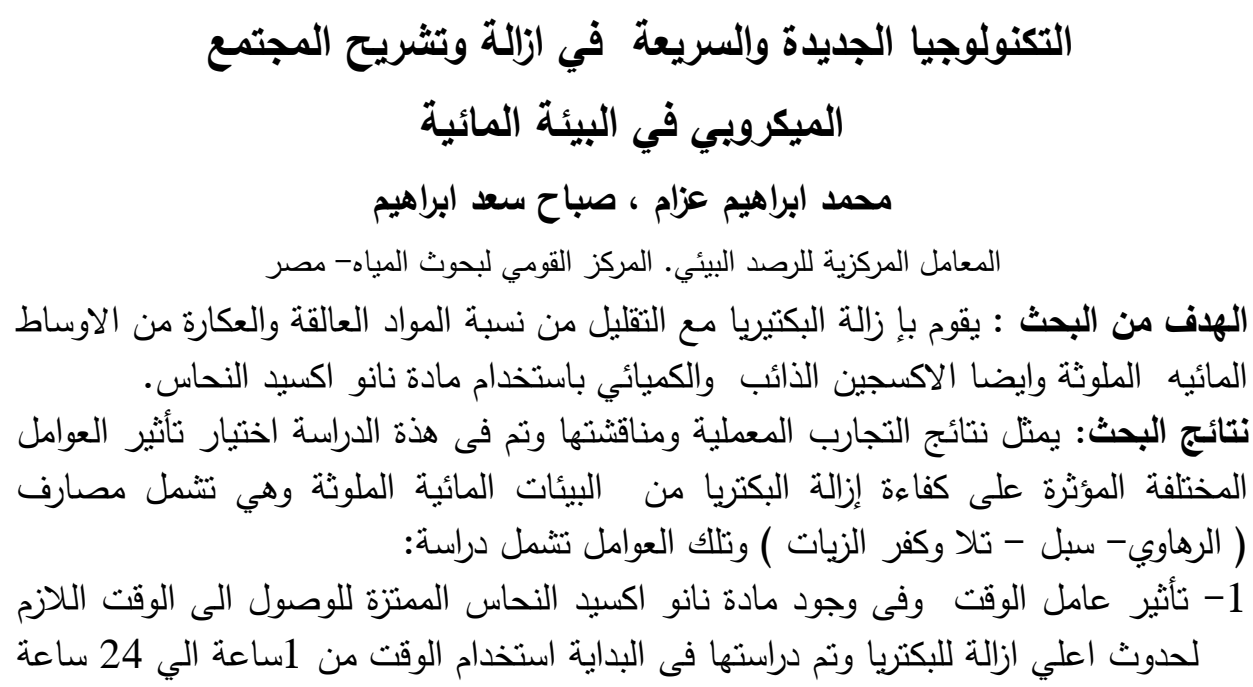


في وجود نانو اكسيد النحاس تكون معدل الازالة للبكتريا تزداد مع زيادة الوقت فتكون

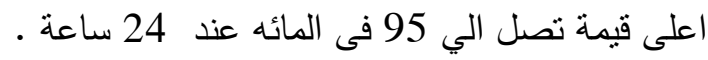

2- تأثثر درجة الحرارة من 10-35 درجة سيلزيوس فى إزالة البكتريا باستخدام مادة نانو اكسيد

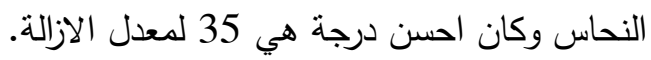

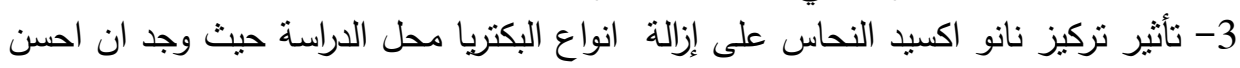
تركيز هو 1 جرام في اللتر تاني

4-تاثير درجة الحموضة عرام على معدل الازالة للبكتريا محل الدرسة كانت اعلى معدل للازالة في وجود Cuo -TOAB

5- تأثنير معدل الرج على معدل الازالة للبكتريا بزيادة معدل الرج تزداد معدل الازالة مع زيادة

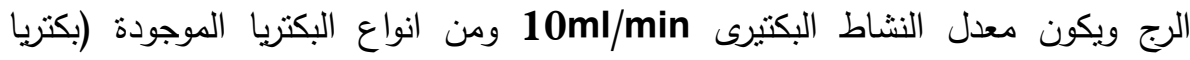

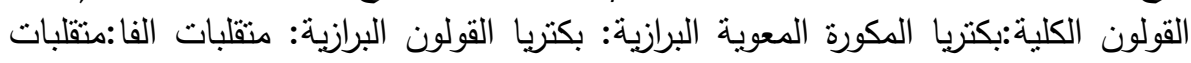

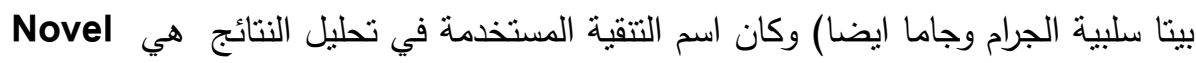
Swage Water Bacterial Disinfection technique Illumina Squencing Technology الملوثة وكذاك كمية الحامض النووي الموجود في العينة . 